\title{
AN INVESTIGATION OF THE ROLE OF ENTREPRENEURSHIP AGENCIES FOR ENTREPRENEURSHIP DEVELOPMENT IN NIGERIA
}

\author{
Solomon Akpoviroro Kowo ${ }^{1, *}$, Olalekan Owotutu Sabitu ${ }^{2}$ and Kadiri Bola ${ }^{3}$ \\ ${ }^{1}$ Department of Business and Etrepreneurship, Kwara State University, Malete Nigeria \\ ${ }^{2}$ Department of Business Adminsitration, Ogun State Institute of Technology Igbesa, \\ Ogun State Nigeria \\ ${ }^{3}$ Department of Business Administration, University of Ilorin, Nigeria \\ *Corresponding author
}

Cite as: KOWO, A.S., SABITU, O.O., BOLA, K. (2019). An investigation of the role of entrepreneurship agencies for entrepreneurship development in Nigeria, Ekonomicko-manazerske spektrum, 13(2), 6880.

Available at: dx.doi.org/10.26552/ems.2019.2.68-80

\begin{abstract}
The study was designed to explore the role of entrepreneurship agencies in enhancing entrepreneurship development in Nigeria. This paper investigates the challenges, problems facing the entrepreneurship agencies in Nigeria. The research paper utilized an explanatory qualitative approach based on the in-depth interviews with ten Nigerian Organizations based in Ogun State Nigeria. The research also brought to knowledge the several challenges with entrepreneurship agencies in Nigeria including poor planning and execution of the programmes, general indiscipline of the officials and beneficiaries, inadequate funding, lack of coordination of the programme. The study demonstrates the need for the Federal Government of Nigeria, Organizations and Entrepreneurs to see the importance and perceived benefits of entrepreneurship agencies for entrepreneurship development. It is recommended that developing countries particularly Nigeria should adopt a good strategic plan on gainfully engaging the youth because youths are regarded as the future of the nation and the act of indiscipline by the officials of these agencies and beneficiaries should be eradicated.
\end{abstract}

Keywords: entrepreneurship, entrepreneurship agencies, entrepreneurship development, entrepreneurial, Nigeria

\section{JEL Classification: J2, J6}

\section{Introduction}

The importance of entrepreneurship in many countries is well pronounced that has made developed nations to discover the importance of the small and medium scale enterprises while the developing countries are still not on the track. (Arminda, 2011) Entrepreneurship is a process that recognizes opportunities in the environment or society which involves mobilizing resources in providing improved goods and services with the aim of profit maximization as a reward of risk-taking. (Ajonbadi and Ugoji, 2014) Mwasalwiba (2010) posits that there has been a tendency to use interchangeably the concept of entrepreneurship government policies and entrepreneurship agencies. The determinant of entrepreneurship ideally represent issues or factors in the borderlines between the strictly personal level factors and the external level factors affecting entrepreneurship which are regarded as a support system. (Abdelgawad and Zahra 
2013) In regards to government support policies and agencies, it was assumed that since the Federal government is in the frontline to contribute towards entrepreneurship development, it should create ways for the availability of resources within its capability. Such resources include the provision of the conducive business environment to organizations and society that will enhance entrepreneurship development. Supporting agencies in relation to entrepreneurial practice is targeted at encouraging entrepreneurship by providing a suitable environment for the entrepreneurs. It was perceived that entrepreneurship development can be attain through procedures and rules that will regulate entrepreneurial activity with the aim that entrepreneurship is the solid rock of a nation's path to industrialization (Ogundele, 2012) Entrepreneurship agencies supporting system are being seen as a key for attaining economic development through wealth creation, employment creation, and good competitiveness of the existing SMEs. Some researchers emphasized that if there is employment generation as well as an increase in the number of entrepreneurs or SMEs, economic development or growth usually takes place. Moreover, it is generally acknowledged by research that entrepreneurship agencies are the key of entrepreneurship development. This support system is seen as the agencies or determinants for entrepreneurial development (Ogundele, 2012). Which is the focus of this study?

The objective of the study: 1. To determine the role of entrepreneurship agencies on entrepreneurship development. 2. To investigate the moderating effect of government policies of entrepreneurship agencies and entrepreneurship development.

\section{Literature review}

\section{The Concept Entrepreneur, Entrepreneurship and Entrepreneurial}

The concept entrepreneur was derived from a French word entrepreneur meaning to undertake, go between or projector (Creswell, 2009). The concept of entrepreneur in the $17^{\text {th }}$ century was a person who engaged in the contractual agreement with the constituted Authority of a Nation to perform a service or to supply a specific product. (Cantillon, 1755) The modern term came to stay in England in 1879. (Mill, 1849) During the $18^{\text {th }}$ century research has shown that individual with capital was distinguished from the person who needed capital today regarded as (venture capitalist) the major reason for this differentiation was industrialization occurring in (Europe and Americas). In the $19^{\text {th }}$ century, entrepreneur was not distinguished from the manager and it was viewed from the economic perspective. The entrepreneur organizes and operates an enterprise for profit or personal gain (Weber, 1904). During the $20^{\text {th }}$ century, many theoretical speculations were postulated about entrepreneur role and his psychological attributes and personality which involves other factors that affect his performance and many more started with the work of Schumpeter that argue that entrepreneur creative and innovative individual was a decisive factor in the process of economic development. (Amstrong, 2009) Issues and findings on entrepreneur have been observed which attention is on Millennium Development Goals specifically in the Less Developed Countries (LCD).

Amit et al. (1993) posit that entrepreneurship as the process of maximizing profit from new market and valuable resources in an uncertain business environment. Entrepreneurship is regarded as an innovative process of converting an idea into marketplace reality by exploiting opportunities (Druncker, 1985). Ogundele (2012) emphasized that entrepreneurship is a process of emergence behaviour and performance of entrepreneurs. He further expresses that entrepreneurship refers to the activities of individual entrepreneurs.

The word Entrepreneurial is the adjectival form of the word entrepreneur. It is used to qualify a person, situation, an organization or a group of people who are exhibiting behaviour of 
entrepreneurs. An organization that is view as being entrepreneurial will exhibit in it structural and behavioural components those features that best describe organization and are established and managed by creative empire builder. Entrepreneur behaviour can be regarded as feelings attitudes, event, action and sentiment of the entrepreneur (Stevenson and Gumpert, 1985, Aguilera et al., 2019)

Entrepreneur performance is referred to behaviour viewed from qualities of performance of what it takes to be successful (Moberg, 2014). He further highlights three dimensions of performance which are the practice of innovation, the practice of entrepreneurial management and the practice of entrepreneurial strategies which involves converting innovation into market place reality.

\section{Entrepreneurship Theories}

Economic Theory: From the economists' point of view economic incentives are regarded as the main motivators for entrepreneurial activities. Entrepreneur is regarded as a human being who see business opportunities, making use of scarce resources as an opportunity. (Thomas, 2013) Entrepreneurship development occurs when economic conditions are sustainable. Moreover, economic incentives are being referred to taxation policy, industrial policy, sources of finance and raw material, infrastructure availability, investment and marketing opportunities, access to information about market conditions, technology among others which has enhanced the positive responses of entrepreneur behaviour and performance (Ogundele, 2012)

Sociological Theory: This can be regarded as a socio-cultural approach or view of entrepreneurship. Which has helped entrepreneurs in the provision of capital, business information and ideas which influence the performance behaviour of entrepreneur (Collins, 2012). An entrepreneur is seen as a person who performs according to his role expectations in the business environment. This thought view society's values, religious beliefs, customs, taboos influence the business environment. (Tavis, 2017)

Psychological Theory: This school of thought focuses on personality traits. Singlemindedness, control, behaviour towards money, need for high achievement, vision, foresight, ability to face opposition, power etc. These features are formed during the child first stage which is base on standards of excellence, self-reliance and dominance. (Mathema and Davis 2005)

Innovation Theory: This view entrepreneur as being creative in the ideas of products combination. Introducing a new product, a new production method, entry a new market, endowing resources with new wealth, combination or introducing a new source of raw material, supply. Introduces new organization policies and rules in any industry (Opeifa, 2013). An entrepreneur is the one who is innovative, creative and has a foresight (Moberg, 2012). This school of thought emphasized on innovation, ignoring the risk-taking responsibility and abilities of an entrepreneur. (Sule, 2014)

Political Theory: This is concerned with a need for achievement. Political factor influence entrepreneur performance and behaviour in society. Government legislations, bye-laws, decrees, bills have been a determinant factor for entrepreneur growth and performance. (Ajonbadi and Ugoji, 2014) Ogundele (2012) discussed the creation of Yaba Industrial Estate for use by indigenous entrepreneurs, the establishment of training centres and Financial aids by the government to indigenous entrepreneurs through National Directorate of Employment (NDE)provision of infrastructures and other support agencies have enhanced the entrepreneurial development processes in Nigeria.

Technological Theory: This involves the use of equipment, tools, machines in the manufacturing and production of goods and services. (Cardo, Davis and Matheme, 2005; Bond 
and Lang, 2018) The use of these machines and tools has influenced the development of indigenous entrepreneurs which has led to fast adaptation.

Managerial Theory: This approach is based on the opportunity and skills to achieve the goal and objectives of entrepreneurs. Management skills have a direct effect on entrepreneur performance and behaviour which enhance and promote entrepreneurship (Galloway and Brown, 2002) this view regards strategic management practices as a function of entrepreneur.

Development Theory: This focus on the development of entrepreneurial skills which is regarded as an extension of the process of occupational choice of the individual, at the macro level it involves training and development in opportunity awareness, market and dealing with government agencies and relevant public technology. The micro-level deal with attitude, work experience, motivation, need for achievement (get success with one's own efforts) need for affiliation. (Osuagwu, 2001)

Educational Theory: This involves society general level of education. It discusses the need for the individual to look at the world around them in a more organized and coordinated way which will add to entrepreneurial performance. (Arminda, 2011) Moreover, the need for entrepreneur to acquire skills and knowledge is a requirement for achieving success. Entrepreneur education is the model for changing attitude. (Mario and Arminda, 2011) Mario and Arminda emphasized that entrepreneur education seeks to develop people most especially the younger age to be enterprising, responsible to become entrepreneur thinkers, creative, innovative thinkers and contribute to economic development and growth. The educational process could assist in an accurate perception of opportunities and can have an effect on entrepreneurship emergence behaviour and performance. (Aluko, 1993, Schmutz and Sidibe, 2019)

Motivation Theory: It can be regarded as acquired needs theory. It is a view that a person has three types of needs at any at a given time, which are needed for achievement that means to get success with one's own efforts. Need for power to dominate, influence others. The need for affiliation maintains friendly relations with others. The need for achievement is the highest for entrepreneurs. (Ajonbadi and Adekoya, 2017)

\section{Empirical Framework}

Killy (1971) investigate the performance behaviour of indigenous entrepreneurs in the bakery industry in Nigeria. He found out indigenous entrepreneurs were vigorous and effective in their perception of opportunities and acquisition of resources in running an organization. Killy (1971) highlighted the factors that have been affecting the performance of entrepreneur which are Introduction of a new production of techniques and products. Production management, Financial Management, Dealing with Public bureaucracy, Marketing products and responding to competition, Management of human relation product quality within the firm, Upgrading process and product quality, Gaining command over scarce resources etc. Ogundele (2000) posit that entrepreneurship as a multidimensional phenomenon.it was observed that behaviour of entrepreneur emerges not by a single but multiple factors from different perspective or views: structural, ethical, innovation, economic, sociocultural, experimental, developmental, educational, ecological etc. He suggested that for policy design in Nigeria all these factors must be addressed because they influence changes in the behaviour of indigenous entrepreneur. Ajonbadi and Adekoya (2017) explore the role of entrepreneurship agencies in promoting management entrepreneurship capabilities in Nigeria organizations. The study analysed the strength and weakness of entrepreneurship education and agencies, method and approach to examine their prospects. It was found out that there is a need for top management, line managers and employees to see the importance of perceived benefit of entrepreneurship agencies and education in developing employee's managerial skills for entrepreneurial 
development. The study concluded that there is a need to continue in a reliable research in Nigeria organization that will help in solving problems related to entrepreneurship agencies, educational training in promoting management entrepreneurial capabilities. Harris and Rowe (1966) investigate the origin of performance of indigenous entrepreneurs in related to government agencies for entrepreneurship development. They found out that capital shortage was not a serious problem in the development of various industries, however, it was observed that poor standard of financial management by entrepreneurial was responsible for the poor performance of established government agencies and policies, they called this defects in the technical and management competencies. Adekoya and Olatunji (2017) focus on the prospect and challenges of setting up a small scale business in Nigeria using a Bank of Industry as a case of study. He examines the effect of entrepreneur capabilities in relation to entrepreneur agencies as catalysts for business growth. He concluded that an entrepreneurial agency in relation to capabilities has a positive effect on the prospect and challenges of setting up a small business.

Agencies for Entrepreneurial Development in Nigeria

The National Directorate of Employment (NDE) as established by the federal government of Nigeria in November 1986 which reduce the unemployment rate among college graduate with strategies executed under four core programmes which are (1) The small scale industries and graduate employment and vocational skills which is to assist the government in employment generation with the development of small scale enterprises in the rural areas of the country. This was to achieve five objectives which are: The graduate job creation; Mature peoples programme; skilled youth job creation loan scheme and the rural exportable craft for women (2) The Agricultural programme (3) National Youth employment and vocational skills development (4) Special public work programme (Okunsanmi, 1990) Moreover Peter Dara (1988) emphasized that NDE is also involved in the following activities (5) Promotion of international trading by finding markets for our products and for our factors of production (6) Entrepreneurship programme (EDP) in the Nigeria Educational system in the curriculum of tertiary institution (7) Intensification of rural employment creation. Ogundele (2012) noted that number of reasons were given for the exhibition pattern of perception regarding NDE which are as follows: Inadequate funding, lack of coordination of the programme by NDE staff, lack of adequate guidance, poor planning and execution of the programme, coercive attitude of NDE officials, loans falling into wrong hands, lack of adequate publicity and education of the public, there is a lot of waste and much cost not avoided, trainers are not trained etc. Ogundele (1987) emphasized that NDE is both a developmental and financing support system which other institution charged with financing responsibilities which are: Small industries credit scheme; The Nigeria Bank for Commerce and Industry(NBCI); Nigeria Industrial Development Bank(NIDB); National Economic Reconstruction Fund(NERFUND); Small and medium Entrepreneur Loan Scheme(SMELS); The peoples Banks and State government. Okeowo (2007) mentioned that Nigeria Opportunities Industrialization Centre (NOIC) was established in 1990 with his headquarter in Lagos that trains its students through the small enterprise development (SED) courses on how to establish their own business units after their training. Furthermore, Rural Agro-Industrial Development Schemes(RAIDS)was established in 1981 as a unit of the federal ministry of Agriculture, Water Resources and Rural Development with the world bank technical support (RAIDS,1988) RAIDS 1998 terms are as follows (1) To determine and develop small scale food processing and storage techniques to meet the needs of rural communities (2) Promote awareness of the needs of the small scale businessman in the field of agro industry (3) Provide skill training to both management and project staff in operational techniques. Moreover, Directorate of foods, Roads, and Rural Infrastructure (DFRRI) which was established in $7^{\text {th }}$ February 1986 with emphasis on rural industrialization through local raw 
materials and traditional skills or adapted technologies. Other agencies for entrepreneurial developments are Raw materials Research and Development Council (RMRDC) which was established in 1987 with the following aims which are noted as follows (1) To encourage growth of research and development capacity (2) To draw up policy guidelines and action programmes on raw material acquisition exploitation and development (3) To advise on adaptation of machinery and processes for raw material utilization.

\section{Problems of Nigerian Entrepreneurs}

The Nigeria business entrepreneurs were being faced with challenges of perplexing situations in their business organizations which can be seen as threats or limiting factors which has a negative effect on the survival of entrepreneurial agencies and growth of entrepreneur's business enterprise in Nigeria (Lawal, 2006). Thomas (2013) states that the problems of Nigeria entrepreneur can be of internal environmental forces and external forces or influences. This internal forces affected the working system which is the main element of the internal environment which are finance, planning, production, personnel, marketing. The forces that influence an enterprise within the same environment can be regarded as external forces or influences (Ogundele 2013). Sulaimon and Adebayo (2006) discussed further on the internal forces and suggested solutions to the problem which are highlighted below:

*Wrong Choice of Business: Entrepreneur makes the wrong decision in choosing a wrong investment which can lead to failure or crisis in business enterprise. An overcrowded business should be avoided. Entrepreneur should be creative and have innovative ideas and skills in entering a new market.

*Lack of Expert: This factor as being a major determinant and success of entrepreneur's survival. Expert knowledge is important for entrepreneurship growth and survival

*Wasteful Expenses: Entrepreneurs must be of essential minimum in order to avoid wasteful and excessive expenses.

*Unethical Business practices: These forces attributed to business failure if not properly managed. The major ones are poor quality products, dishonesty, indiscipline among employees and staffs, bribery and corruption.

*Location Problem: If business is not well situated this might have an effect on customers which may affect the smooth running of the enterprise.

*Personal Characteristics: Entrepreneurs are the victims of their own circumstances; entrepreneur's characteristics have a major impact on the survival of the business enterprise.

*Inventory Problem: Purchase of slow moving products and overstocking of the product will have a cost implication which is a problem to the survival of a business

*Marketing Problem: This occurs in many ways which include non-standardization of product, inappropriate pricing, unstandardized strategies promotion of products or services etc.

*Lack of Employees Satisfaction: Autocratic leadership style of leaders can have an effect on the enterprise. Poor conditions of work in terms of wages and salaries can affect the smooth running of an enterprise. If employees are not well motivated this may affect the level of productivity of the employees.

*Lack of Qualified Manpower: Unskilled workers have a negative effect on the growth of an enterprise. Most small business enterprises do not have the financial strength to employ skilled manpower due to financial constraints

* Over Stretching of Credit: Most small business organization who are eager to make sales often extend undue credits to customers, without appropriate methods of cash collections

*Poor Financial Management: If there are no proper financial and accounting records this will have a significant effect on the organization. Entrepreneur should develop or create proper accounting records of their business to enhance the survival of the enterprise. Moberg (2014) 
the external factors are forces that cannot effectively be controlled by entrepreneurs. These factors are relevant for the survival and growth of the enterprise and must be properly monitored. The external problems confronting enterprises in Nigeria include among others are highlighted. (Moberg, 2014, Easterby-Smith, 2011, Verbeke and Fariborzi, 2019)

*Competition: Competition among giant firms takes unethical dimensions. Small scale businesses are being faced with competitions against larger corporations which have led to closure and failure of many small business enterprises in Nigeria.

*Finance or Capital Problem: Most small enterprise have the problem of securing fund due to lack of collateral. Working capital is a vital tool for survival of an enterprise.

*Technological Problem: Technological competition from the global environment has affected small business enterprise in Nigeria.

*Shortage of Raw Material: Shortage of raw materials which has led to a reduction in production output of small business enterprises.

*Bad or Poor Policy Framework: Government interventions, regulation laws of government entrepreneurial agencies from local, state and federal government have to be a problem to Nigeria entrepreneur since independence.

\section{Methodology}

This research aimed at investigating the role of entrepreneur agencies for entrepreneurship development in Nigeria. Evidence was taken from selected organizations. Management of these organizations has undergone various entrepreneurship programmes and policies which makes data required to be visible. The study is of exploratory nature. Eaterby-Smith et al (2008) state that management research is regarded as research that involves science of finding out information through the development of knowledge and adopted methodology. The qualitative approach is adopted for this study. The use of qualitative research enabled the researcher of a better understanding of the nature of entrepreneurship agencies with possible issues that might arise through interaction with the key respondents. Qualitative techniques in this research help the researcher to draw an in-depth view of all the entrepreneurship agencies and performance rate for entrepreneurial development. This research adopted the interview and focus group data collection method in collecting information from recipients. The in-depth interview conducted in this research covered a variety of selected Locations/Cities in Ogun State Nigeria. This research work applied the use of snowballing sampling techniques which enabled the researcher to cover ten organizations that are small-medium scale businesses. Moreover, this research adopted a semi-structured interview method. The interviews were audiotaped but firstly putting in mind all ethical requirements by seeking the participants' consent before beginning with the interview session which was followed by a series of outline questions. This question focuses on the role of entrepreneur agencies and the moderating effect of government agencies for entrepreneurship development.

\section{Results}

The interviews conducted enabled the researcher to gather some data to validate our research questions. The opinion and views of the respondents in relation to entrepreneurship agencies were investigated with the interviews questions that were structured.

Notions of Entrepreneurship Agencies in Nigeria Organization:

The employees of the selected organizations were asked what they understand and the meaning of entrepreneurship agencies. 
The quotations below were drawn from the views of the respondents:

Entrepreneurship agencies are referred to as support system which is established that covers both personal and environmental in nature, which includes such determinants as politics, values, and attitudes of support system either public or private with the framework of improving entrepreneurship practices and growth for entrepreneurial development. (Chief Accountant $-\mathrm{M}$ \& M Enterprises Nigeria Limited)

Entrepreneurship agencies are agencies whose goal is to help develop and support the growth and survival of entrepreneur within a specified city, region or state by providing necessary resources and assistance. Providing sources of information and assistance for the start-up of businesses and expanding business in the state, region and local for entrepreneurial development. (CEO- Adestar \& Sons Nigeria Ltd)

They are public, private or most often a public/private programmes, and their purpose is to promote entrepreneurial growth and development in the areas they serve. They accomplish their goals and objectives by encouraging new businesses to locate in a targeted or specific area. They give guidance on planning, supervision, discipline and the need for training to enhance entrepreneurial growth in the society. (Manager-Soloking \& Sons Enterprises)

Entrepreneurial Agencies can be regarded as a programme of activities to improve the knowledge, skill, behaviour and attitudes of individuals and groups to enhance the capability of entrepreneurs with the aim of building successful programmes in different parts of Nigeria to help entrepreneurs to achieve their objectives. This also comes with the minimizing risk with training exposure and reducing the crime rate by solving the unemployment problem. (Managing Director - Galead Investment Limited)

Entrepreneurial Agencies can be seen as Federal Government adopted strategies and policies towards entrepreneurial development by establishing Institution and body, which provide a variety of support services to entrepreneurs. These Institutions and Agencies are established to contribute towards entrepreneurial development in the area of funding, execution of programmes, vocational skills and development, skilled youth's job creation and loan scheme etc. (Logistic Officer - Macfolam Nigeria Limited)

The entrepreneurial agency can be defined as the transformation of firms, markets, industries by the evolving interaction of temporally situated, intentional strategic action with a malleable external environment to complement prevailing viewpoints on the survival of the small business enterprise. Furthermore these institutions and bodies are established to solve the entrepreneur's problem which among others are poor planning and execution of programmes, general indiscipline, poor planning and execution of business activities and lack of adequate guidance. (Manager - oluwalogbon \& sons Nigeria limited)

In our enterprise entrepreneurial agencies are institutions or bodies regulated by public or private to enhance entrepreneurial development through organized training programmes for small-medium enterprise with necessary tools that will twist their thinking towards bringing up certain innovative ideas that will contribute towards enterprise growth, Moreover this institution also focuses on provision of finance and training in one package thus removing frustration and provision of employment generation. Examples are (NDE) National Directorate of Employment, The small Scale Industrial and Graduate Employment Development, Nigeria Opportunities Industrialization Centre (NOIC) Project development Institute (PRODA), Rural Agro Development Scheme (RAIDS). The Administrative staff college of Nigeria (ASCON), The risk fund scheme etc. (Human Resource Manager - Dimo ENTERPRISES Nigeria Limited)

Entrepreneurial agencies can be regarded as a developmental programme, policies and opportunities awareness support system embarked on adaptive research and development programmes which have established processing systems, promotion of innovations and ideas 
An investigation of the role of entrepreneurship agencies for entrepreneurship development in Nigeria Authors: Solomon Akpoviroro Kowo, Olalekan Owotutu Sabitu, Kadiri Bola

of existing operations and market expansion. Promotion of international trading by finding markets for our products and for our factors of production etc. (CEO - A\&AFisheries Limited)

From all the views of the respondents on entrepreneurship agencies it can be said that these definitions are linked to the definition of Ogundele (2012) that states that Government agency in relation to entrepreneurial practice is targeted at encouraging entrepreneurship by providing a suitable environment for the entrepreneurs which can be achieved through procedures and rules that will regulate entrepreneurial activity with the aim that entrepreneurship is the solid rock of a nation's path to industrialization. He further emphasized that Entrepreneurship agencies are being regarded as a key for enhancing economic development through wealth creation, employment creation, and good competitiveness of the existing SMEs. Entrepreneurship agencies are the key to entrepreneurial development, this support system is seen as the agencies or determinants for entrepreneurial development. (Ogundele, 2012, Otokiti, 2013)

Notion of Entrepreneurial agencies and Entrepreneurship development:

The respondents were asked questions on what their opinion on the role of entrepreneurial agencies for entrepreneurship development and some of the responses are as follows:

On behalf of our company, I will discuss the role Entrepreneurial agencies for entrepreneurial development in the area of Leadership. Leadership strategic management of the business organization in Nigeria is mainly determined by the attitude of the entrepreneur and his effectiveness as a leader and by the results he achieves. Strategic leadership reduces poor planning and execution of programmes, there is proper supervision of projects and adequate guidance for entrepreneurs which has enhanced the survival of small-medium enterprises in Nigeria. (Manager - Adestar and Sons Nigeria Limited)

Entrepreneurial Agencies as Institutions has helped Nigeria entrepreneurs in Strategic Decision-making. To be entrepreneurial, it requires that the entrepreneur must be innovative and creative, mostly in the aspect of strategic decision-making. He must have confidence in himself and have the ability to make a good business decision. Strategic management in the entrepreneurial development in Nigeria has enhanced strategic decision-making. The bigger an organization, it becomes more complex and uncertain compared to other organization decisions, strategic decision entails the long-run future of the entire enterprise. In my company the proposed strategic decision-making process for entrepreneurial development is composed of the following five interrelated steps: (i) Developing the main business idea, (ii) scanning and assessing the factors that affect the external environment (iii) scanning and assessing the forces that affect the internal environment, (iv) analyzing the strategic factors using SWOT analysis(v) generating a good business plan and indicating how to transform the idea into reality. (Human Resource Manager - M\&M Enterprises Nigeria Limited)

Entrepreneurship agencies have enhanced entrepreneurship development in risk-taking. The attractiveness of a particular strategic alternative is partially a function of the amount of risk it entails. the amount of assets that entrepreneur must allocate to an investment, the strategy and the length of time the assets will be productive for the entrepreneurial development is now well effective because there is now adequate guidance and proper planning. Risk occurs more often in a small business enterprise in Nigeria than in large established cooperation. The following strategic management approach is adopted in our company in the aspects of taking decisions in conditions of uncertainty which are as follows: balancing potential success against potential loss whether or not he choose a "risky" alternative or a conservative alternative which depends on, the attractiveness of the alternative, the level to which he is prepared to accept the potential loss, the relative probabilities of success and failure, the rate of which one's efforts increase the 
likelihood of success and decrease the likelihood of failure. (Manager - Dimo ENTERPRISES Nigeria Limited)

Notion of Management Entrepreneurial Capability in Nigeria Organizations:

The respondents were asked questions on what their opinions on the concept of management entrepreneurial capabilities and some of the responses were as follows:

Management entrepreneurial capability is the conjoined efforts of an organization to build intrapreneurial capabilities for its employees. That means the employee is embodied with the ability to take risks, drive innovations, create the impossible and act as a decision-maker. (CEO - Macfolam Nigeria limited)

In my opinion, I perceived management entrepreneur capability as the ability of employees and staffs of an organization to compete with other organizations and have a competitive edge over others through innovation and the ability to be creative with managerial skills and ideas. (Human Resources Manager - Galead Investment Nigeria Limited)

Management entrepreneurial capability from my own view is the capability of entrepreneur to act as an entrepreneur even though he is an employee. The staffs or employee create opportunities from need or wants of the populace and turn them into satisfaction which serves as a positive effect in achieving the company goals and objectives. (Accountant - Aderupopo Farm Nigeria Limited)

Management Entrepreneur capability is the managers, employees or staffs ability to identify opportunities and utilizing these opportunities for organization profitability and effectiveness. (General Manager - Oluwalogbon and Sons Nigeria Limited)

Notion of Challenges facing Entrepreneurship Agencies in Nigeria Organization It was important to hear their views on challenges facing entrepreneurship agencies in respect of their various organizations:

Despite the impact of entrepreneurship agencies on the staffs and organizations, yet we still have challenges facing this entrepreneurs supporting system known as the agent of entrepreneurship. From my own view, some of the problems facing these agencies are: lack of coordination of programmes, poor coordination of programmes, generally poor implementation of funding and general indiscipline at both the levels of beneficiaries and officials has been the major problem that has led to failure and collapse of these entrepreneurship agencies in Nigeria. (Manager Director - Fasil Nigeria Limited)

Entrepreneurship agencies in Nigeria have been facing challenges in the area of entrepreneurship education with respect to training and development. Many of these training institutions or consulting firms have made a lucrative job out of these training programmes since they have perceived the urgent need of various organizations wanting to train their employees. Another factor is the inability of these agencies and consulting training firms to purchase modern learning standard facilities which will aid more improvement. In Nigeria the role of entrepreneur agencies in promoting entrepreneurship education for entrepreneurship development as not being really explored. (Director of Training and Development A\&AFisheries Limited, Osuagu, 2002)

From my own point of view, the challenges facing the entrepreneurial agencies among others include: There is a lot of waste and many costs could be avoided. The coercive attitude of the agencies staffs, sometimes their programmes is limited in the scope of coverage, Loans that were supposed to be given to the small scale enterpriser often fall into wrong hands, poor planning of these agencies and interest in the programme agencies lack control and supervision etc. (CEO-Soloking \& Sons Enterprises)

Regarding the challenges being faced by entrepreneurship agencies in Nigeria, I will focus my view on general indiscipline of the officials of the agencies and the beneficial or 
organization at large. The issue of various forms of indiscipline is a problem confronting entrepreneurial agencies and entrepreneurs. the various aspect of indiscipline are corruption, dishonesty, theft, fraudulent practices, cheating, smuggling, laziness, disloyalty, lack of trust, lack of the spirit of enterprise, embezzlement, nepotism, truancy from work, dishonest business associate and inadequate weighing measures. (Marketing Manager - Macfolam Nigeria Limited)

\section{Discussion}

This is the summary of the findings and investigations based on the interview conducted during the study. The respondents revealed the following:

a) What is the role of Entrepreneurship Agencies to Nigeria's Economic Development?

i. Entrepreneurship agencies have contributed immensely to Nigeria's entrepreneurship development with the findings it has created more employment for job seekers;

ii. The bad or poor economic situations have affected entrepreneurship agencies to promote Nigeria's economic development.

iii. Corruption and nepotism of the agencies have been an obstacle to entrepreneurship development to below expectation; hence no significant contribution has been recorded.

iv. The high rate of unemployment that was recorded in the economy shows that no better improvement has been made in the area of entrepreneurship development.

v. Lack of adequate and access to capital has hindered some of the agencies and bodies to achieve the aims and objectives of their establishment.

\section{b) As Entrepreneurship Agencies Power the Economy of Nigeria}

Over $50 \%$ of the respondents believe that there are no enough entrepreneurship agencies that can power the economy. This implies that although there are many entrepreneur agencies and bodies across the nation, their positive contributions and capacities are largely negligible.

c) Government Policies, Agencies and Interventions are the Survival and Growth of Entrepreneurship Development

i. Government bodies and agencies, such as the Directorate of Employment (NDE), the small scale Industrial and Graduate Employment Development, The project development institute (PRODA), Nigeria Opportunities Industrialization Centre (NOIC), Rural Agro Industrial Development Scheme (RAIDS), Raw Materials Research and Development Council (RMRDC), Federal Institute of Industrial Research Oshodi (FIIRO) has supported the survival and growth of entrepreneurship in Nigeria.

ii. The lack of adequate guidance and programme limited in the scope of coverage has hampered the growth and survival of many entrepreneurs in the nation.

iii. Political instability has been affecting the growth and survival of entrepreneurs in the country.

iv. Inadequate security and diversity in societies and communities has greatly hindered entrepreneurs.

v. Misuse of the fund by government agencies and microfinance institutions has a significant effect on the survival of entrepreneurship development in Nigeria

d) Does Entrepreneurship Agencies bring Wealth Creation and Employment Opportunities

i. Entrepreneurship has fostered wealth creation and created employment in Nigeria extensively. 
ii. Entrepreneurship is a vital instrument for the creation of wealth and employment opportunities.

iii. Entrepreneurship agencies have enhanced the provision of employment opportunity, training and stimulated the emergence of new organizations thus helping entrepreneurs to realize their objectives.

\section{Conclusion}

The aim of the study was to investigate the role of entrepreneurship agencies in promoting entrepreneur development in Nigeria. The important of Entrepreneurship agencies and way to make it function were inclusive. This research concludes that entrepreneurship agencies have not actually achieved economic development. This research found that Entrepreneurship agencies play a crucial role in the economic growth and development of any nation. In order words, there is a veritable link between entrepreneurship agencies and entrepreneurship development. Entrepreneurship agencies are necessary supporting systems to foster the economic development of any nation. However, entrepreneurship agencies programme has not improved living standards of the populace, has remained a great challenge in the country. Nigeria business environment and government policies and programmes are quite unstable which a barrier to entrepreneurship development. Entrepreneurship agencies can enhance the sustainability economy development by creating employment generation and improving the level of small scale entrepreneurs in Nigeria. It is necessary to enhance the prospects of entrepreneurship agencies in Nigeria with the aim of reviewing the National Policy on Education and creating a clear National Policy on Entrepreneurship to re-orientate Nigerians.

\section{Recommendations}

The study recommends that Nigeria Government should adopt a good strategic plan on gainfully engaging the youth. Nigeria youths are regarded as the future of the nation. Several governments' regimes are establishing entrepreneurship agencies. More so they are putting much emphasis on the need to train future entrepreneurs through infusing entrepreneurship components within the educational option, especially at the tertiary level. Some countries have taken this initiative to a higher level by introducing entrepreneurship education at elementary school and encouraging them to be future entrepreneurs when they are of age.

Policymakers should recognize the importance of entrepreneurship agencies to economic development. It is the entrepreneur that translates the innovation in science and technology into wealth. Entrepreneurship agencies should be seen as vital tools for entrepreneurship development. The Federal Government of Nigeria should make sure that there is proper policy coordination and policy stability. There have been several government interventions and programmes by entrepreneurship agencies that aimed at promoting entrepreneurship but no significant impact on Nigeria's economic development.

The best way to eliminate poverty that is endemic in Nigeria is by encouraging youths, particularly those with identified entrepreneurial skills to go into private business particularly in science and technology because these have natural potentials for business development which will enhance the standard of living of the populace. The act of indiscipline by the officials of these agencies and beneficiaries touched on the issues of values and attitudes.it is pertinent to note that indiscipline in whatever form is a behaviour act. Therefore there should be a body that will checkmate this conduct, Economic and Financial Crimes Commission (EFCC) and Independent Corrupt Practices and Other Related Offences Commission (ICPC) were put in place as support systems to deals with people involved in the act of indiscipline but till date, the crusade of corruption is still on the high side. 


\section{References}

Abdelgawad, S.G., Zahra, S.A, Velikowa, S.S. \& Sapienca, H.J. (2013). Strategic leadership and entrepreneurship capability for game change. Journal of Leadership and Organization Studies, 20(4), 394-407.

Aguilera, R.V., Marano, V. \& Haxhi, I. (2019). International Corporate governance: A review and opportunitie for future research. Journal of International Business Studies, 50(4), 457-498.

Amstrong, M. (2009). Amstrong Handbook of Human Resources Practice (1 $1^{\text {th }}$ Ed). London: Kogan Page Limited.

Bond, T.N. \& Lang, K. (2018). The black-white education scaled test-score Gap in Grades K-7. Journal of Human Research, 53(4), 891-917.

Creswell, J.W. (2009). Educational Research: Planning, Conducting and Evaluating Qualitative and Quantitative Research. (2 $2^{\text {nd }}$ Ed.).

Easterby-Smith, M., Thorpe, R. \& Jackson, P.R. (2011). Management Research. (3 ${ }^{\text {rd }}$ Eds.) London: SAGE Publications.

Federal Ministry of Industries (1986). Federal Secretariat Abuja, Entreprenuership Development Programme (EDP) Work-For Yourself Model, Participants Manual, Presented at Western Regional entrepreneurship education workshop,LASU Badagry, 27 $7^{\text {th }}$ May- $5^{\text {th }}$ June 1991.

Galloway, L. \& Brown, W. (2002). Entrepreneurship education at university: A driver in the creation of high growth firms? Education Training, 44(8/9), 398-404.

GEM (2008). GLOBAL Entrepreneurship Monitor Executive Report 2008. GEM.

Killy, R. (1971). Entrepreneurship and Economic Development. New York: The Free Press.

Lawal, A.A (2006). Management practices and Organization effectiveness in Nigeria small and medium Enterprises. Unpublished PhD Thesis Akoka Lagos.

Moberg, K. (2012). The impact of entrepreneurship education and project based education on student personal and development and entrepreneurial intensions at lower level of educational system: Too much of two good things.

Moberg, K. (2014). Two approaches to entrepreneurship education: The difference effect of education for and through entrepreneurship at lower secondary level, International Journal of Management Education.

Ogundele, O.J.K, (2000). Determinants of entreprenueurial emergence, behavior and performance in Nigeria.

Ogundele, O.J.K. \& Ogbojafor, A. (2004). Application of bounded opportunity approach to the studies of some indigenous entreprenueurs in Nigeria. Global Journal of Accounting, and Department of Accounting University of Lagos Akoka, 1(2), 209-219.

Ogundele, O.J.K (2012). Management and Organization: Theory and Behavior, 2nd Edition, Lagos: Malofin Nominees.

Ogundele, O.J.K and Hassan, O.R (2010). Ingredients for global dominance in Africa Entreprenuership. Journal of Oriental and African Studies, 9,123-145.

Okeowo, S. (2007). NDIC has infrastructures that some polytechnics do not have. National Mirror, 5(8), 25.

OECD (2013). Determinants of Entrepreneurship Selected Indicators. Entreprenuership at a Glance, OECD Publishing.

Otokiti, SO. (2013). Institutional roles in entrepreneurship development in Nigeria- Landmark University. Entreprenuership Model: Paper Presented on the Occasion of the $2^{\text {nd }}$ Entrepreneurship Director Conference of Kwara State University Malete Nigeria.

Osuagu, L. (2002). Entrepreneurship in a developing economy, empirical evidence from Nigeria business Organizations. International Journal, 6, 9-32.

Schmutz, B. \& Sidibe, M. (2019). Frictional labour mobility. Review of Economic Studies, 86(4), 1779-1826.

Sule, M. (2014). The role of Entrepreneurship education on job creation among youths in Nigeria. International Letters of Social and Humanistic, 15, 87-87.

Thomas, E. (2013) Entrepreneurship: A working definition. Harvard Business Review.

Ugoji,C., Mordi C. \& Ajonbadi, H. (2014). An investigation into training and development techniques, prospects and challenges in Nigeria Banks. Journal of Research and International Business Management, 4(2), 37-44.

Verbeke, A. \& Fariborzi, H. (2019). Managerial governance adaptation in the multinational enterprise: In honour of Mira Wilkins. Journal of International Business Studies, 50(8), 1213-1230. 